\title{
Stabilization as the securitization of Peacebuilding? The experience of Brazil and MINUSTAH in Haiti
}

\author{
Thomaz Napoleão ${ }^{1}$ \\ Mariana Kali1 ${ }^{2}$
}

The acknowledgement that many vulnerable societies relapse into violence in the aftermath of the withdrawal of peacekeeping operations has underscored the imperative of developing sustainable exit strategies. Stabilization has hence emerged as a possible means to promote short-term security while avoiding direct political responsibility over complex crises, but the meaning of the term and its consequences remain disputed. The aim of this contribution is to examine the conceptual, academic and diplomatic debate over the concept of stabilization in peace operations by addressing the case of the United Nations Mission for the Stabilization of Haiti (MINUSTAH), and Brazil's multidimensional role in it.

In February 2011, when presiding over the United Nations Security Council (UNSC), Brazil drafted a Presidential Statement on the interdependence between security and development for the maintenance of international peace and security (S/PRST/2011/4). In 2005, the issue had received special treatment in the UN system, namely when the UN Peacebuilding Commission (PBC) was created alongside with the recognition of a conceptual and empirical range for peace that could only be translated

\footnotetext{
${ }^{1}$ Thomaz Napoleão (MSc in International Security, Paris Institute of Political Science/Sciences Po; MA in Diplomacy, Rio Branco Institute/IRBr) is a Diplomat at the Permanent Mission of Brazil to the United Nations. The views expressed here are personal and do not represent the Government of Brazil in any way.

${ }^{2}$ Mariana Kalil (PhD Candidate in History of International Relations, University of Brasília/UnB) is a Professor at the Department of Defense \& International Strategic Management of the Rio de Janeiro Federal University (DGEI/UFRJ) and at the Institute for Strategic Studies, Fluminense Federal University (INEST/UFF), besides representing Latin America at ISA Global South Caucus' Executive Committee.
} 
into actual security, or the settlement of threats, if perceived via a multidimensional strategy.

Brazilian Foreign Policy had long advocated the inclusion of development among debates on international security, but recently the country broadened its grasp of development, inserting not only criticisms of wealth concentration and the urge to social justice, industrialization and macroeconomic stability (Kalil, 2012). Brazil has come to terms with the unstable realities of the aftermath of the Cold War, in which the interlink between development and security is evidenced by the need to generate electricity, improve infrastructure and establish transparent legal systems to attract investors and provide job opportunities in order to tackle the roots of conflict. Having acquired the status of an emerging power based on its macroeconomic stability and the inclusion of millions into the middle class within a highly urban society, Brazil was now able to engage in international security issues in a less self-concerned way.

Although Brazil's military might remains only moderate, the country now engages in international defense cooperation in light of its economic and political stability. The democratic aggiornamento of Brazilian armed forces was underscored by official documents such as the National Defense White Book, the National Defense Strategy and the National Defense Policy. It would be tantalizing to downplay such involvement, since the former metropolises' or the Western States' military outreach - or even that of Russia and China - are substantially more ambitious than Brazil's. Nonetheless, here might lie one of Brasília's key contributions to conceptual and theoretical thinking regarding war and peace: the possibility of furthering national interests through military involvement while actually promoting security and prosperity for the local population. There could be a voluntary positive sum between defending geopolitical objectives and fostering a sustainable peace in fragile contexts. Without disregarding the political selectivity behind 
the UNSC decisions on matters of peace and security, the international community could actively engage in peacekeeping operations that might be more successful in creating a sustainable peace - as long as certain approaches to the concepts of peacebuilding and stabilization are clearly identified within the scope of the resolution.

Brazil's military leadership of the United Nations Mission for the Stabilization of Haiti (MINUSTAH), as this article discusses, faces dilemmas that are familiar to other contributors of troops to peacekeeping operations, in Haiti and elsewhere. Nonetheless, the way the country's military personnel deal with such challenges suggest a unique strategy, be it voluntary or not. The launching of projects such as Light and Security in Cité Soleil and the choice of intoning the Haitian anthem before a raged riot instead of resorting to pure use of force, even though the latter course of action would be authorized by the mission's mandate, illustrate how Brazil's agency in issues that encompass the tools of Hard Politics manages to fuse hard and soft power in what transcends Nye's (2004) synthesis of a smart power.

The 2011 Brazilian interpretation of the interdependence between security and development finds in Haiti its concrete expression in terms of the successful provision of a sustainable peace - or perhaps stability. The Brazilian Battalion's slogan 'Strong Arms; Friendly Hands' epitomizes such transcendence. The phrase illustrates the fundamental construction of a safe environment through the actual, imminent or dissuasive use of force. Besides, it affirms that such involvement would carry within itself the responsibility of offering a positive experience regarding what should represent a brand new chapter in the population's perception and trust in institutions. Yet, the slogan conveys the idea that Nye's (2004) soft and hard powers could gather to represent more than the smart power, but an actual overlap between the exercise of influence via cultural features, political values, foreign policy, capital and guns. Brazil's Foreign Policy has been 
largely successful in portraying the image of a global player with a particular role in Latin America and in peace and security.

Brazil's cultural traces and political values, in turn, represent an asset to deal with Haiti's local realities. Brazilian economic vigour also provided the country with capabilities to exert real influence especially in the field of cooperation for development a fact which represents an international benchmark in light of Brazil's political values and socially inclusive domestic policies. The military presence in Haiti, thus, could represent the embodiment of most of Brazil's agency in the international arena.

In this sense, Brazil's domestic reality may be a useful laboratory for the country's diplomacy. As citizens of a former colony and a developing nation, Brazilians are used to corruption scandals and confusions between the public and the private spheres. This was intensified by a late industrialization process and a rather recent development of democratic institutions, including the Constitution itself, which is only 26 years old (Braveboy-Wagner, 2003). Such a recent institutional maturing allowed the Brazilian state to be conscious of realities that resemble that of fragile states, while having surpassed dim predicaments, especially in the twenty-first century. Indeed, an interview with a Brazilian military during a night patrol in Cité Soleil has revealed how a soldier born and raised in Rio de Janeiro understands the dynamic of the largest Haitian slum. On record, he did not hesitate to argue that Cité Soleil would be just like any other favela in Rio. The only differences were Haiti's extreme poverty and some cultural quirks such as the importance of not asking men to take of their shirts during, for instance, a security check.

Measuring or even considering cultural elements as capabilities is a Herculean task, and one that is not going to be the core preoccupation of this article (Kalil, Hamman, Muggah, 2012). Nonetheless, the Brazilian approach to peacebuilding, particularly in the context of MINUSTAH, will be contrasted with controversial agendas of stabilization that 
were stealthily put forward by certain developed countries at the United Nations. The broader academic debate over the concept of stabilization will also be addressed.

The main goal of this contribution is thus to address the interdependence between security and development within the emerging concept of stabilization based on the United Nations' experience in Haiti from 2004 until 2014, as well as Brazil's role in this enterprise. We will examine the current concepts and doctrines (or lack thereof) regarding the notions of "stability" and "stabilization" within the UN. Literature on the concept of stabilization will be used, besides such primary sources as UN documents, reports and data, as well as field research undertaken by both authors in several Haitian cities in December 2014 that included visits to local communities and development projects, as well as interviews with diplomats, Haitian citizens and international military, police and civilian personnel, especially those under the guise of MINUSTAH. Chatham House rules were assured to those interviewed, thus offering them a safe environment to address notthat-comfortable issues related to the current and future challenges faced by peacekeepers in the country. Also, theoretical background is to be taken into account, such as Campbell's (1992), Tickner's (2002), Weber's (2005) and Bilgin's (2011) input on securitization.

A key question this article intends to ask is whether stabilization has been practiced as a form of securitized peacebuilding, and MINUSTAH provides relevant empirical data to investigate this claim. Bensahel, Oliker \& Peterson (2009), Muggah (2009; 2014), Mac Ginty (2012) and Coning, Muggah \& Cunliffe (2014) present key debates on the rise of the concept of stabilization within the UN system. Their contributions should entail further research on the shifting political usage of these concept by the permanent members of the Security Council (P5), particularly the United States, in light of factors such as the 
evolution of public opinion and the interests of bureaucratic civil services within these countries.

Clearly, political will is paramount for any type of change. New and more sustainable approaches to peacekeeping, possibly to be proposed by the UN High Level Independent Panel on Peace Operations in September 2015, could move beyond traditional discussions on the legitimacy of international interventions and have special relevance for the practices of a highly politicized and selective UNSC. Conceptual debates on the uses of stabilization should encompass not only the limits and opportunities for the use of force, but above all an understanding of the level of international interference, including through military means, to be deemed acceptable and legitimate by the countries and societies involved.

The first part of this article carries the current application of the term stabilization in peacekeeping operations under the umbrella of the United Nations, as well as in other debates within the organization, such as that involving the Post-2015 Development Agenda. This will raises the question of whether stabilization is the revalidation of traditional strategies under the justification of better intentions regarding the sustainability of peace.

Brazilian Foreign Policy both in discourse and practice, especially in the landscape of MINUSTAH, is addressed in the second part of this article. The country's perspective on the interdependence between security and development spills over to an understanding of peacekeeping and peacebuilding as necessarily concomitant in the field of fragile contexts. As we will see, Brazil challenges the notion that holds stabilization as a separate - and even rival - endeavor within the wider efforts of peacebuilding. In the third and final part of this contribution, we will examine the stabilization and peacebuilding activities led by Brazil in Haiti while seeking clues on how the concept of 
stabilization may be designed to encompass a long-term and multidimensional approach to sustainable peace that is based on a true commitment to a broad peacebuilding strategy, rather than a limited and circumstantial military engagement.

\section{An elusive and controversial concept}

The politically loaded concepts of stability and stabilization remains ill-defined in the ever-growing literature on international peacebuilding and statebuilding. It has been argued that stabilization differs from peacekeeping in that it attempts to "achieve peace by managing or removing an aggressor", while the aim of peacekeeping is "to arrive at and maintain a cease-fire and/or implement a peace agreement among the parties to a conflict" (Coning, Muggah, Cunliffe, 2014). According to another definition, stabilization constitutes "a 'transition' from large-scale peacekeeping operations in areas affected by widespread insecurity to smaller-scale program with targeted security and development packages" (Muggah, 2014). Other authors have deemed "stabilization forces" a mere synonym for "peace support operations" with robust implementation mandates (Chetail, 2009).

Most Western official doctrines contain wide-ranging definitions on these controversial words. The United States Institute of Peace sees stability as "the tendency of a state or a nation to recover from perturbations and resist sudden change or deterioration" and stabilization as "ending or preventing the recurrence of violent conflict and creating the conditions for normal economic activity and nonviolent politics" (USIP, 2009). Also from a US strategic perspective, the Rand Corporation describes stabilization as "the effort to end conflict and social, economic and political upheaval", and one 
component of a wide range of operations that may include counterinsurgency, counterterrorism and reconstruction (Bensahel, 2009).

Current NATO doctrine states that stabilization and reconstruction activities entail "support to establishing long-term stability and strengthened governance, local capacity building and the promotion of ownership by the relevant national authorities, encouragement of the rule of law and establishing the basis for economic, human and social development" (NATO, 2011). The UK Ministry of Defence understands stabilization as "the process that supports states which are entering, enduring or emerging from conflict in order to: prevent or reduce violence; protect the population and key infrastructure; promote political processes and governance structures which lead to a political settlement that institutionalizes non-violent contests for power; and prepares for sustainable social and economic development", adding that "its ultimate purpose is to strengthen an existing political order, or to reshape it, to become more acceptable to that nation's population and more consistent with the UK's strategic interests" (UKMOD, 2009).

But detractors of these forceful definitions are legion, most of whom are also skeptical about the effects of the so-called "liberal peace" (Paris, 2009, Chandler, 2010, Campbell, 2011), comprising Western-inspired institution-building and policymaking, on fragile or post-conflict scenarios. Mac Ginty offers a particularly relentless critique on the political usage of stabilization, pointing out the complications regarding the chosen indicators and the means of applying such surveys, but especially the emphasis on the protection against crime and violence instead of other preoccupations that would be more urgent to the concerned population. As the author underscores: "The ascent of stabilization needs to be examined within the wider context of the securitization of aid and peace-support intervention" (Mac Ginty, 2012). The author's understanding of 
securitization slightly differs from that of other thinkers, as he states it would be 'the prioritization of security and the security lens, especially in the development and aid spheres where traditionally notions of empathy and moral compassion held sway (Mac Ginty, 2012)'. Campbell's (1992), Tickner's (2002), Weber's (2005) and Bilgin's (2011) input on securitization brush up the idea by grasping it as the recognition of a threat to one's own security. Hence, the action based on the securitization of a reality would offer fertile ground to the politicization of events. When stability choses the securitized path of peacebuilding, it would fall into this category, what can be rather useful to a not-sodemocratic UNSC.

Likewise, Curtis argues that stabilization ("order through coercion and military power") is the most conservative framework for peacebuilding, as opposed to the rival approaches of peacebuilding as liberal governance (developing the state and its formal institutions, including electoral democracy and a free market) and peacebuilding as social justice (empowering vulnerable actors and tackling inequality within and between countries) (Curtis, 2013). Given such debate, the next part of this chapter offers a brief history of the treatment of stabilization in the United Nations political practices.

\section{Stability, stabilization and the United Nations System}

While Kofi Annan's 2005 report In Larger Freedom effected direct results within the structure of the United Nations, including the establishment of the PBC, an influential 2009 document launched by the Department of Peacekeeping Operations (DPKO) and the Department of Field Support (DFS) (United Nations Peacekeeping Operations: Principles and Guidelines, known as the "Capstone Doctrine") renewed the multilateral conceptual debate on peacekeeping and its contemporary challenges. Evidently informed by 
developments on the ground, and in particular the debacles of Rwanda, Bosnia, Somalia and the two Congo wars, these discussions dated back to the milestone 1992 report $A n$ Agenda for Peace and the subsequent controversy on the legitimacy of humanitarian intervention that ultimately led to the adoption of the concept of Responsibility to Protect by the 2005 World Summit.

Yet this intellectual tour de force omitted any meaningful definition of the words "stability" and "stabilization" in the context of peacekeeping operations and related endeavors. The glossary of the Capstone Doctrine noticeably fails to define these terms, even if the document contains a graph vaguely suggesting that stabilization might be the initial phase of a peace consolidation effort, when post-conflict tasks in twelve extremely varied areas (infrastructure; employment; economic governance; civil administration; elections; political process; security operations; disarmament, demobilization and reintegration [DDR]; rule of law; human rights; capacity building; and humanitarian assistance) could be fostered by the United Nations and its partners.

In many ways, stabilization might therefore be the missing link of the conceptual, academic and diplomatic debate regarding UN peacekeeping since the end of the Cold War.

In spite of, and perhaps because of, this terminological vacuum, the Security Council has authorized no less than five peacekeeping, peace-enforcement or peacebuilding operations bearing the word "stabilization" in their titles in recent decades - the NATO-led Stabilization Force in Bosnia (SFOR, 1996) and the UN missions in Haiti (MINUSTAH, 2004), the Democratic Republic of the Congo (MONUSCO, which replaced MONUC in 2010), Mali (MINUSMA, 2013) and the Central African Republic (MINUSCA, 2014). 
The specific security challenges facing these five operations were in fact very dissimilar, and the same could be said about their respective political contexts. In the case of SFOR, "stabilization" meant the forceful implementation of a peace agreement (the 1995 Dayton Accords); otherwise said, the NATO-led mission was essentially a fortified version of a traditional peacekeeping operation, as it was meant to separate belligerent parties with their consent on the aftermath of a war. MINUSTAH, on the other hand, was deployed to a country with no armed conflict and actually deprived of a standing Army; the "enemy" to be vanquished was the very weakness of the Haitian state and society, struck by both political fragility and economic and environmental vulnerability (GAUTHIER, 2010). When establishing MINUSTAH through Resolution 1542 (2004), the Security Council explicitly stated that the "challenges to the political, social and economic stability of Haiti" posed a threat to international peace and security in the region. Lastly, the three stabilization missions launched in Africa since 2010 were attempts to solve highly complex crises, where long-running domestic conflicts were aggravated by chronic underdevelopment and the insufficient legitimacy and effectiveness of concerned states, often the heirs of artificial colonial entities. The case of MINUSMA, in particular, should also be understood through the prism of the so-called "war on terror", as the northern region of Mali (the Azawad) had effectively seceded and hosted a multitude of Saheli jihadist groups between 2012 and 2013, a fact which led to frequent comparisons with Afghanistan under Taliban rule.

Additionally, the objectives of "stabilization" and "stability" have been raised by the resolutions that established missions in Kosovo (UNMIK, 1999), Sierra Leone (UNAMSIL, 1999), Liberia (UNMIL, 2003 - explicitly defined as a "stabilization force" by its mandate), Côte d'Ivoire (UNOCI, 2004), Timor-Leste (UNMIT, 2006), South Sudan (UNMISS, 2011) and Abyei (UNISFA, 2011), as well as UN-authorized multinational 
forces in Afghanistan (ISAF, 2001) and Somalia (AMISOM, 2007), respectively led by NATO and the African Union. Even UN special political missions, wholly civilian in nature and linked to the Department of Political Affairs instead of the Department of Peacekeeping Operations, have resorted to the ambiguous language of stabilization, as in Guinea-Bissau (UNIOGBIS, 2009), Burundi (BNUB, 2010), Libya (UNSMIL, 2011) and Somalia (UNSOM, 2013).

While the actual approaches of these missions vary widely, a singularly relevant case is the robust mandate guiding MONUSCO since 2013, when the Security Council authorized an Intervention Brigade able to employ offensive action to "neutralize armed groups" in eastern Congo and decided to pursue "stabilization through the establishment of functional state security institutions in conflict-affected areas, and through strengthened democratic order that reduces the risk of instability, including adequate political space, observance of human rights and a credible electoral process"' (SCR 2098). MONUSCO military action was to be complemented by a complex framework of civilian activities, including an International Security and Stabilization Support Strategy (ISSSS) to gather resources to strengthen state control over eastern DRC; a government-led Stabilization and Reconstruction Plan (STAREC); and the innovative concept of "islands of stability", fragile areas where MONUSCO would help government forces restoring authority through the delivery of basic public services - from hospitals to police stations and the physical denial of presence for rebel groups. This civilian-military initiative echoes the counterinsurgency model applied by NATO during its 2009-2011 surge in Afghanistan ("clear, hold, build, transfer"), and even the recent "pacification" of some of Rio de Janeiro's slums.

Notwithstanding the unique case of MONUSCO, UN peacekeeping missions are far from adopting a unified and coherent answer to the challenges facing peace and 
security around the world. Aware of this shortcoming, Secretary General Ban Ki-moon established a High Level Independent Panel on Peace Operations in October 2014, under the leadership of José Ramos-Horta, former President of Timor-Leste, with a one-year mandate. The Panel will review legal, political, military and budgetary issues concerning both peacekeeping operations and special political missions. Its recommendations will be considered by the General Assembly at the start of its $70^{\text {th }}$ Session, in September 2015, and it is plausible that a long-overdue definition of stabilization in the context of peacekeeping will be among them.

Interestingly, the only Brazilian member of the Panel, Lieutenant General Floriano Peixoto Vieira Neto, was twice deployed to MINUSTAH, each time during crucial junctures: as a Brigade Operations Officer in the mission's first year (2004) and as Force Commander between 2009 and 2010, a tour of duty that included the earthquake that devastated Port-au-Prince in January 2010.

Concurrently with the work of the Ramos-Horta Panel, in 2015 the UN is also promoting a ten-year review of its Peacebuilding Architecture - comprising the Peacebuilding Commission (PBC), the Peacebuilding Fund (PBF) and the Peacebuilding Support Office (PBSO) - with a view to increasing its overall performance. The terms of reference of the Peacebuilding review were proposed by Brazil, as the 2014-2015 Chair of the PBC. While avoiding the sensitive conceptual debate on the connotations of stability, the review will inter alia "study the areas of potential complementarity between the PBC and relevant UN operational entities", as well as "the emerging gaps and constraints that limit the effectiveness and ability of the United Nations to prevent the recurrence of conflict" (Letter from the Permanent Represent of Brazil to the President of the General Assembly, November 4th, 2014). In short, while the meaning of stabilization will not be under discussion, the ways and means to foster stability ("the tendency of a state or a 
nation to recover from perturbations and resist sudden change or deterioration", to recall the USIP definition) in post-conflict environments will be in the spotlight.

It should be noted that the multilateral impasse regarding the meaning of stability and stabilization is not restricted to the Security Council and other peacekeeping and peacebuilding bodies such as the $\mathrm{PBC}$, but also - and controversially - encroaches on other UN activities.

Sustainable development is the prime example. During the discussions on the Post2015 Development Agenda and the forthcoming Sustainable Development Goals (SDGs), the General Assembly gathered on a thematic debate entitled Ensuring Stable and Peaceful Societies in April 2014. The background presentation assumed that "peace and security, development and human rights are the three pillars of the UN system and foundation for collective security and well-being" (Concept Note, Thematic Debate of the General Assembly "Ensuring Stable and Peaceful Societies", 2014). Panels debated the nexus between sustainable development, peace and stability; the strengthening of national institutions as a means for sustainable peace; and the role of global awareness and partnerships to ensure stable and peaceful societies (Background Note, Ibid).

One of the documents on which the debate relied was People's Voices on Stability and Peace, designed by the initiative The World We Want, a global survey led by the United Nations that reached 1.8 million people across the globe between 2012 and 2014. While no clear definition of stability was provided, the choice of indicators used to verify consciousness over instability was revealing and thus worth quoting: (a) a good education ; (b) better healthcare ; (c) an honest and responsive government ; (d) better job opportunities ; (e) access to clean water and sanitation ; (f) affordable and nutritious food ; (g) protection against crime and violence ; (h) freedom from discrimination and persecution ; (i) support for people who can't work ; (j) protecting forests, rivers and 
oceans ; (k) better transport and roads ; (l) equality between men and women ; $(\mathrm{m})$ political freedoms ; (n) phone and internet access ; $(\mathrm{o})$ reliable energy at home ; $(\mathrm{p})$ action taken on climate change (People's Voices on Stability and Peace, 2014). Protection against crime and violence was highlighted as one of the key concerns of the interviewed citizens, along with complaints over honest and responsible governments, better job opportunities and freedom from discrimination.

Yet the stated objective of the General Assembly debate ("to ensure that building stable and peaceful societies is an essential part of the international effort to achieve sustainable development", Background Note, Ibid) was tantamount to the partial securitization of the Post-2015 Development Agenda. A number of industrialized countries, assisted by civil society organizations funded by them, proposed a stronglyworded SDG with specific quantitative objectives regarding violence reduction, access to justice and the tackling of corruption and illicit financial flows - all seen as key elements to build "stable societies" based on a supposedly universal and inflexible notion of "rule of law". This move was firmly opposed by Brazil and other countries of the Global South, which argued that the departure from a "rights-based approach" toward a "rule-of-lawbased approach" of development would encourage the imposition of unjust conditionalities for development assistance and thus politicize the development discourse, while blurring the fundamental distinction between "conflict" (an issue of international security) and "violence" (a domestic affair), potentially allowing a rather oligarchic decision-making organ cherry pick what is and what is not a threat to peace and security. Ambassador Patriota of Brazil questioned the "misperception according to which conflict and instability can only be generated in weaker or poorer regions" and reminded that peace and security was not one of the pillars of the Rio+20 Outcome 
Document, which set the parameters for the Post-2015 Agenda (Statement by Brazil and Nicaragua on VIII OWG-SDGs, February 2014).

While a specific SDG (Objective 16) on "peaceful and inclusive societies" was eventually agreed upon, the fact that the lengthy outline of the Post-2015 Development Agenda excludes the word "stability" and its variants, and imposes no measurable goal on peace and security, may rightly be seen as a substantial achievement of Brazilian Foreign Policy (Report of the Open Working Group of the General Assembly on Sustainable Development Goals, A/68/970).

\section{The Brazilian way}

Having discussed the international controversy on the concept of stabilization, we now examine the perspective advocated by Brazil in the case of Haiti. In order to verify whether stabilization in Haiti means essentially a securitized approach to the concept of peacebuilding, one must understand how Brazil's participation in MINUSTAH differs from conventional multilateral practices regarding stabilization.

The interviews conducted by the authors in Haiti reveal the widespread local perception, among both Haitian citizens and international policymakers, that Brazil's engagement in MINUSTAH represents a juxtaposition - not merely a sum - of the concepts of hard and soft power. Far from being perceived as agents of a neo-colonial or neo-imperial power, Brazilian personnel in Haiti, whether military or civilian, tend to be respected even by those who are highly skeptical over the international presence in the Caribbean country. Mindful of its limitations but also aware of its comparative advantages as an international cooperation partner, Brazil does not aim to compete with developing countries in terms of aid flows or humanitarian assistance to Haiti. Instead, 
Brasília designed (or rather "learned by doing") a more progressive approach to stabilization that is founded on a unique "soft/hard" formula for peacebuilding. Thus Haiti became a "laboratory of multi-sector engagement" for Brazilian policymakers, to borrow Waisbich and Pomeroy's (2014) expression - with the important caveat that the "laboratory" was not just seen as a sandbox or a means to achieve greater influence, but treated as an end in itself.

Instead of the threat of physical coercion or the imposition of governance institutions, peacebuilding à la brésilienne features bottom-up and demand-driven development projects; empowering public policies aimed at tackling poverty; nonintrusive support to security sector reforms, including the training of police officers; a gradually emerging, if still imperfect, willingness to welcome a growing Haitian diaspora in Brazil; and, above all, a deep sense of respect for the receiving society that results from historical and cultural proximity. The importance of the latter element in Haiti, a country where resentment with past foreign interventions still runs high, cannot be overstated.

Indeed, former President Jean-Bertrand Aristide (2011), whose political influence survives through the resilience of the Lavalas movement, blames the West, particularly France and the United States, for Haiti's social, economic and political problems - a perspective not at all uncommon in contemporary Haiti:

All earthquakes are earthquakes/But there is one that is unparalleled in bringing destruction./ (...) Sunday April 4, 2010, a powerful earthquake/Measuring 7.2 hit Mexico./Results: 2 people died, 100 or so were injured./And yet the earthquake that hit Haiti/ Measured 7.0 and caused nearly 300,000 deaths./ (...) Colonists and new colonists consider poor people/ Like sweet mangos that they can suck, eat and throw 
away./This is why the foreign soldiers who showed up in 2004/And in $2010 \mathrm{did}$ not come to give the poor security./Colonization is wrapped inside rosy speeches, beautiful promises/While weapons are there to defend the interests of the new colonists (Aristide, 2011).

This mindset - what Aristide calls "philosophical reflections for mental decolonization" and Braveboy-Wagner (2003) identifies as a common trait between the heirs of Cold War's Third World thinking - is directly connected to the debate over the concept of stabilization, as discussed among diplomats and scholars. It is no coincidence that Brazil, a country with a complex international identity but resolutely and deliberately not seen as a Western developed nation, usually escapes from being held accountable for Haiti's hardships, in spite of a full decade of military deployment and civilian presence.

The credibility of Brazilian blue-helmets remained relatively unscathed even after incidents that seriously hampered the public image of the United Nations in Haiti, notably the outbreak of cholera that was allegedly traced to the Nepalese contingent of MINUSTAH in 2010. While MINUSTAH's own legitimacy has been disputed by officials who believe that Haiti simply does not pose an international threat (Seitenfus, 2010) and authors that warn about allegations of human rights abuses by UN troops, notably those of Sri Lanka (Edmonds et alii, 2012), these serious criticisms were usually aimed at the mission itself or at other national battalions - not those of Brazil.

In fact, the opposite is true: the public appeal of Brazilian peacekeepers never waned. As interviews with UN political advisors in Port-au-Prince suggest, Brazilian conflict resolution initiatives are seen by local actors as a key factor in the substantial improvement of the security panorama in Haiti since 2004, notwithstanding the stillubiquitous poverty and the political crises and natural disasters that frequently hit the 
country. Notable examples include grassroots mediation activities implemented on a daily basis by MINUSTAH troops in Cité Soleil and community violence reduction programs enacted by NGO Viva Rio in Bel Air (Muggah, 2010). Meanwhile, Brasília established Port-au-Prince as its prime technical cooperation partner and launched a large number of South-South development projects - crucially, according to priorities set by Government of Haiti - in areas such as food security, sanitation, rural development, public health and basic education. Even if not all projects were successful, the Brazilian preference to support national authorities, instead of the incoherent multitude of civil society organizations that made Haiti infamous as the "Republic of NGOs", was and remains highly appreciated in the country $(A B C, 2010)$.

The constructive civilian and military presence of Brazil in Haiti is complemented by a coherent diplomatic discourse on the Caribbean country's immediate and long-term needs:

Brazil has a long-term commitment to Haiti. The strengthening of State institutions through capacity-building initiatives is a priority for stability in Haiti. Particularly relevant is the goal of increasing Haiti's National Police capabilities, the only way to ensure perennial appropriation of security provision by Haitians themselves. We commend MINUSTAH's work regarding the implementation of quick impact projects and community violence reduction programs that contribute to the mutually reinforcing and inextricable objectives of stability and development. As we ponder on the lessons learned from our experience in Haiti, QIPs stand out as one of the most positive instruments in building a safe and stable environment. (Statement by Brazil at the Fourth Committee of the UN General Assembly, October 30th 2013) 
The dual emphasis - stability, but also development - is perceived by Haiti as contrasting with other international engagements. Its relevance becomes ever more acute as MINUSTAH transitions to its final stage of deployment, since Security Council Resolution 2180 (2014) recognized that "the overall security situation remained relatively stable with some improvement" since 2013 and therefore decided to substantially reduce the force contingent.

The foremost element of the exit strategy envisaged for MINUSTAH - the build-up and training of Haiti's National Police (PNH) - recalls not only the controversy over the legitimacy of the use of force by foreigners in the country, but also the crucial dilemma regarding the role to be played by the country's national coercive institutions. In this context, President Michel Martelly has repeatedly called for the recreation of the Haitian Armed Forces, which were disbanded in the 1990s, although the financial feasibility and political consequences of such an ambitious endeavor remains uncertain.

This complex predicament leads back to the conceptual debate over peacebuilding. Here, once again, Brazil highlights the imperative to build a sustainable peace that is based on the interdependence between security and development; in this regard, however, an approach of peacebuilding based on social inclusion and the resolution of local conflicts is not just understood as a preferable path to peace, but as the only means for peace. In contrast, even when security sector reform is indispensable to enable the receiving country to exercise the monopoly of the legitimate use of force, stabilization in itself is only an incomplete step towards the construction of a lasting peace in a vulnerable society.

Brazil's perspective and behavior as a peacekeeper and peacebuilder is influenced by several factors, including the drive towards international influence and power 
projection through multilateral diplomacy, the practice of "selective solidarity" and the solid belief in the need to foster development worldwide (Nasser, 2012). While believing the Security Council should be ready to deploy blue helmets when demanded by ground realities, Brazil also frequently insists on the fulfilment of traditional requirements of peacekeeping, such as the voluntary consent of the parties, even when the mission has a multidimensional profile and is enabled by Chapter VII of the UN Charter to use force in defense of its mandate. This advocacy can be traced not only to the country's commitment to the upholding of international law, but also to the conciliatory and non-intrusive character of Brazil's international identity and foreign policy.

It is therefore understandable that Brazil sees local ownership - a central notion to the legitimacy of all peacebuilding ventures - as an indispensable path to the attainment of a sustainable peace. In the context of MINUSTAH nearing its drawdown, this entails strengthening national legal institutions, chiefly the $\mathrm{PNH}$ and the judicial system, to enhance their efficiency and credibility among the Haitian population. Ideally, such initiatives should be reconciled with the need to promote social development, postdisaster reconstruction and economic growth; in this regard, the agreement signed in June 2014 to enable the constitution of a 200-strong Haitian Military Engineering Corps, to be trained by the Brazilian Army, is exemplary.

As political violence all too often fuels urban confrontations in the country, particularly in Port-au-Prince, Cap-Haïtien and Gonaïves, forging a healthier relationship between local communities and security agents is essential to build a lasting peace. In the case of Haiti, overcoming cultural resistances to (or fears of) the police, as well as the common habit of bribing, might be achieved through education, even if the process could take generation. Meanwhile, providing local authorities with both the means and the incentives to preserve stability is key to ensuring a successful post-MINUSTAH 
transition, therefore guaranteeing a stable environment and avoiding any relapse into violence.

\section{Towards a post-stabilization Haiti}

It could be argued that to entertain the withdrawal of foreign forces before the consolidation of a strong political tradition of state authority, under the Weberian meaning, might be far-fetched, especially since, as Rodrigues (2010) points out, even under the most well-accomplished rule of law shock, even within one's own reflections, is inherent to human existence. An apparently functional social contract would, thus, inexorably encompass a perpetual state of instability. Notwithstanding, it rests far from consensual the legitimacy of an international military presence in a country where instability is not a clear-cut result of an armed conflict, and rather of sporadic mass or restrict impulse typical to certain local political give-and-take. The highly sensitive political decision, to be taken by the UN Security Council, to consider a specific situation no longer threatening to international peace and security, and therefore no longer requiring a substantial international presence, may be temporarily postponed, as it happened in the aftermath of the 2010 earthquake - but cannot be avoided forever. With careful planning and sufficient resources, gradual transitions to sustainable postpeacekeeping scenarios can be smooth and seamless, as the recent cases of Sierra Leone (post-UNAMSIL, 2005) and Timor-Leste (post-UNMIT, 2012) confirm. The current drawdown of MINUSTAH, particularly following the adoption of Resolution 2180 in 2014, points in the same direction.

Nonetheless, a careful approach to stabilization ought to realize that a sustainable stability is a lot more complex than the simple cease of an explicit threat to international 
security. When the UNSC's perception of stability as the end of a threat to international security even though the State is all but developing leads to the withdrawal of troops, the process of peacebuilding is securitized. Peace is old-fashionably interpreted as the absence of a threat to international security, against all odds of relapse, and so is left by the wayside of history a broader input on the multidimensional features of the military and of peacekeeping operations, which are both overwhelming in the case of Brazil's Battalion at MINUSTAH - although some of it may result from matters of the United Nations' and the supporting States' budgetary circumstances.

While each national context is unique, Haiti has the potential to join the ranks of developing countries where international stabilization as intrinsic steps in broader peacebuilding efforts were mostly successful. A further development, possibly to be reached in 2016 and certainly to be welcomed by Brazil, might be the transference of the situation in Haiti from the Security Council agenda to that of the Peacebuilding Commission after the conclusion of MINUSTAH. The country would therefore still receive international assistance towards the consolidation of its national institutions, the empowerment of its citizens and the inclusive development of its economy, but these endeavors would no longer be framed by a security-oriented standpoint.

A successful post-MINUSTAH transition in Haiti would not, in and by itself, solve the ongoing diplomatic and academic debate on the practices and meanings of stability and stabilization. It could nonetheless prove that stabilization, the "S" of MINUSTAH, can be freed from the slippery logic of securitization and be reconciled with a more responsible, progressive and humane form of peacebuilding.

\section{References}


ABC (Brazilian Cooperation Agency) (2010). Brazil-Haiti South-South Cooperation Program. <http://repiica.iica.int/DOCS/B2173P/B2173P.PDF>

Aristide, J. B. (2011). Haïti-Haitii? Philosophical reflections for mental decolonization. Boulder, Paradigm Publisher.

Bensahel, N.; Oliker, O. \& Peterson, H. Improving capacity for stabilization and reconstruction operations. Rand Corporation.

Bilgin, P. (2011). The politics of studying securitization? The Copenhagen School in Turkey. Security Dialogue.

Braveboy-Wagner, J. A. (2003). The foreign policies of the global south: rethinking conceptual frameworks. Boulder, Lynne Rienner Publishers.

Campbell, D. (1992). Writing security: United States Foreign Policy and the politics of identity. Minneapolis: University of Minnesota Press. Introduction: on dangers and their interpretation.

Campbell, S. et al. (2011). A Liberal Peace? The Problems and Practices of Peacebuilding. London: Zed Books, 2011.

Chandler, D. (2010). International Statebuilding: The Rise of Post-Liberal Governance. London: Routledge, 2010.

Concept Note, Thematic Debate of the General Assembly "Ensuring Stable and Peaceful Societies", 2014.

$<$ http://www.un.org/en/ga/president/68/pdf/sts/Concept_Note_Peaceful_and_Stable_Soci eties.pdf $>$

Chetail, V. (2009). Post-Conflict Peacebuilding: a Lexicon. Oxford: OUP, 2009.

Coning, C.; Muggah, R. \& Cunliffe, P. (2014). In: What needs to change in UN Peace Operations? An expert briefing book prepared for the High-Level Independent Panel on Peace Operations.

Discourse of Brazil's Ambassador to the United Nations, October 30th 2013. MRE.GOV 
Kalil, M.A.C. (2012). Development in Brazilian Foreign Policy. In: First ISA Global South Caucus Conference, Menton, 2012.

Kalil, M.A.C.; Hamann, E. P.; Muggah, R. (2012). Reflection on the Brazilian Effect: a seminar on Brazil's potential to deploy civilian experts to fragile settings. In: Efeito Brasil (2012), Brasília, Post-Event Report.

Letter from the Permanent Represent of Brazil to the President of the General Assembly, November 4th, 2014.

$<$ http://www.un.org/pga/wp-content/uploads/sites/3/2014/12/41114_ten-year-reviewpeacebuilding-architecture.pdf $>$

Mac Ginty, R. (2012). Against $\quad$ Stabilization. $<$ http://www.stabilityjournal.org/article/view/sta.ab/21\#how-to-cite>

Muggah, R. (ed.) [2009]. Security and Post-Conflict Reconstruction: Dealing with Fighters in the Aftermath of War. New York, Routledge.

$<$ http://www.providingforpeacekeeping.org/wp-content/uploads/2014/11/Briefing-BookPK-Final.pdf>

Muggah, R. (2010). The effects of stabilisation on humanitarian action in Haiti. $<$ http://www.alnap.org/pool/files/the-effects-of-stabilization-in-haiti.pdf>

Muggah, R. (2014). The United Nations turns to Stabilization. $<$ http://theglobalobservatory.org/2014/12/united-nations-peacekeeping-peacebuildingstabilization/>

Nasser, F. (2012). Pax brasiliensis: projeção de poder e solidariedade na estratégia diplomática de participação brasileira em operações de paz da Organização das Nações Unidas.

$<$ http://www.ipea.gov.br/agencia/images/stories/PDFs/livros/livros/web_operaes_de_paz _em_um_mundo_globalizado.pdf>

NATO (2011). Political guidance on ways to improve NATO's involvement in stabilisation and reconstruction. 
Nye, J. S. (2004). Soft power: the means to success in World Politics. New York: Public Affairs.

Paris, R. (2002). International peacebuilding and the 'mission civilisatrice' in Review of International Studies, v.28, 2002.

$\begin{array}{lllll}\text { People's } \quad \text { Voices } & 2014 .\end{array}$ $<$ http://www.un.org/en/ga/president/68/settingthestage/6esps.shtml>

Report of the Open Working Group of the General Assembly on Sustainable Development Goals, A/68/970. UN.ORG

Peacebuilding Isn't Always a Force for Good: Interview with Devon Curtis. IPI, July 11, 2013.

Rodrigues, T. (2010). Guerra e Política nas Relações Internacionais. São Paulo: EDUC.

Tickner, A. B. La securitización de la crisis colombina: bases conceptuales y tendencias generales.

UKMOD (2009). Joint Doctrine Publication 3-40. Security and Stabilisation: the Military Contribution. <https://www.gov.uk/government/publications/security-and-stabilisationthe-military-contribution--3>

USIP (2011). Guiding Principles for Stabilization and Reconstruction. $<$ http://www.usip.org/sites/default/files/guiding_principles_full.pdf $>$

Waisbich, L. \& Pomeroy, M. (2014). Haiti - Um laboratório de engajamento multisetorial. $<$ http://obs.org.br/index.php?option=com_k2\&view=item\&id=620:haiti-um-laboratoriode-engajamento-multisetorial>

Weber, C. (2005). Securitising the unconscious: the Bush Doctrine of preemption and Minority Report. Routledge. 